\title{
Landscape evolution during the Middle and Late Pleistocene in the Madrid basin (Spain) vegetation dynamics and human activity in the Jarama-Manzanares rivers (Madrid) during the Pleistocene
}

\author{
$\mathrm{M}^{\mathrm{a}}$ José Gil-García a ${ }^{\mathrm{a}} \mathrm{M}^{\mathrm{a}}$ Blanca Ruiz-Zapata a , Susana Rubio-Jara ${ }^{\mathrm{b}}$, Joaquín Panera ${ }^{\mathrm{b}, ~ *}$, \\ Alfredo Pérez-González ${ }^{\text {b }}$ \\ a Dpto. Geología, Geografia y Medio Ambiente, Campus externo, Universidad de Alcalá, Alcalá de Henares, Madrid, Spain \\ ${ }^{\mathrm{b}}$ Centro Nacional de Investigación sobre la Evolución Humana (CENIEH), Paseo Sierra Atapuerca, s/n. 09002 Burgos, Spain
}

\section{A R T I C L E I N F O}

\section{Article history:}

Received 20 December 2017

Received in revised form

14 February 2018

Accepted 26 February 2018

Available online $\mathrm{xxx}$

\section{Keywords:}

Paleoenvironment

Middle Pleistocene

Late Pleistocene

Landscape reconstruction

Manzanares and Jarama valleys

Iberian Peninsula

\begin{abstract}
A B S T R A C T
The evolution of the landscape surrounding the rivers of the Madrid basin during the Middle Pleistocene is summarised in the present paper. Patterns of adaptation of human populations who settled on the riverbanks have been established in this area through geoarchaeological data recovered from associated deposits, mainly in the Manzanares and Jarama rivers. An exceptional paleoenvironmental record has been documented for the last 379,000 years in the sequences studied in the centre of the Iberian Peninsula. Pollen and non-pollen samples were studied in eight sequences obtained from different sedimentary environments of two terraces, one located in the Manzanares river (Complex Terrace of Butarque) and the other in the Jarama river (Complex Terrace of Arganda), both in Madrid (Spain). The findings show the constant presence of Pinus, sometimes as the prevailing species, and Juniperus as an element of the regional vegetation. The local vegetation is characterised by open Mediterranean forest and riverside woodlands, which together with the aquatic taxa demonstrates the presence of water. The occasional presence of deciduous forest taxa, probably related to riverside woodlands, suggest warmer conditions. Ubiquitous taxa prevail among the herbaceous strata. These types of plants do not require specific ecological conditions, but could suggest a certain degree of humidity and explain the low values of xeric taxa and sub-continental steppe grasslands. The development of nitrophilous taxa, associated with the presence of fauna, is consistent with the faunal remains recorded from the sites. However, the pollen record shows changes in the structure of the vegetation in all sequences (progressive increase in the tree component), as well as in the composition of the plant landscape (decrease of the Mediterranean taxa and increase of xeric and steppe grasslands), due to temperature and humidity rate related changes. Climatic oscillations are observed across the stratigraphic sequence, and discussed in light of the archaeological evidence for the human occupation of inland Iberia.
\end{abstract}

(๑) 2018 Elsevier Ltd and INQUA. All rights reserved.

\section{Introduction}

During the last decades the paleoclimatic studies, together with the diversification of palaeoclimatic records and development of accurate dating methods have allowed the reconstruction of the main changing events with variable temporal resolution. These records, together with advances in our knowledge of the mechanisms that control climatic changes, have revealed the existence of

\footnotetext{
* Corresponding author.

E-mail address: joaquin.panera@cenieh.es (J. Panera).
}

an important natural variability in the system, which works at different temporal scales (Mitchell, 1976; deMenocal et al., 2000; Ruddiman, 2006; Battarbee et al., 2004; Mayewski et al., 2004; Duplessy et al., 2005; Goosse et al., 2005; Nederbragt and Thurow, 2005; Crowley and Hyde, 2008; Fletcher and Sánchez Goñi, 2008; Rodrigo-Gámiz et al., 2013; Margari et al., 2010; Benito et al., 2015), not only the geological scale, but also the orbital ( 100,000 years), sub-orbital $(\sim 10,000$ years $)$ and historic $(\sim 1000-100$ years $)$ scales (Köhler et al., 2010).

The knowledge of the climatic variability of the Quaternary, which has been inferred from terrestrial sedimentary sequences, is still limited, due to the scarce number of sequences and an 
inadequate chronological control. In some exceptional circumstances, favourable geological conditions have provided a relatively unperturbed accumulation of sedimentary sequences, some of which have been identified in Mediterranean Europe (e.g. Tzedakis et al., 2006).

Analysing long chronological periods allows the study of ecosystem dynamics in very different times, including climatic circumstances similar to current ones, although with some particularities, such as the inclusion or not of the footprint of human activity as a landscape modulating agent. However, in Southern Europe there are barely any continental records which provide palaeoecological information for the temporal interval between MIS-11 and the Holocene (Tzedakis, 2010; Tzedakis et al., 2003, 2006, 2013; Lézine et al., 2010; Volgel et al., 2010). This phenomenon becomes more noticeable in the Iberian Peninsula (IP), as documented by Tzedakis et al. (2013). In the current scenario of Global Change (Van Kolfschoten et al., 2003), the areas of the Mediterranean region are more vulnerable to climatic dynamics (Solomon et al., 2007), and therefore must be taken as a system model in the geoscientific agenda.

In this conceptual framework, having the chance to observe the dynamics of the vegetation for the last $c$. 379,000 years of history in an area with virtually no data, such as the central area of the IP, makes the sequences of the Manzanares and Jarama valleys an exceptional record. This sequence is even more interesting as this region is located in a Mediterranean area, and lacks the thermophilic biases that affect most meridional and coastal areas of the Western Mediterranean peninsulae. Thus, the data obtained from this record are unique with regard to their extent and temporal resolution.

Research implemented during recent years on the Pleistocene deposits of the Madrid Basin has allowed an initial approach to the paleoenvironments developed in the valleys of the Manzanares and Jarama rivers, as well as to the adaptation of hominins to a fluvial environment (Rubio-Jara et al., 2016). This data can be completed with the reconstruction of the Pleistocene plant landscape, obtained from a pollen analysis carried out on eight sedimentary sequences (Fig. 1) located in the valleys of the Manzanares and Jarama rivers (Madrid). The purpose is to complete the knowledge of the plant environment in the Middle Pleistocene in the central peninsular area, as well as to establish the climatic variability and its peculiarities in the area, and provide an environmental framework for the activities performed by human groups during the Pleistocene in the valleys of the Jarama and Manzanares rivers (Baena et al., 2002; Panera et al., 2010; Rubio-Jara et al., 2016).

\section{Geographic location}

The eight selected pollen sequences were obtained from archaeological sites identified in fluvial deposits in the area where the Manzanares and Jarama rivers come together (Fig. 1). In this area, the fluvial valleys developed by those rivers are dissymmetric and show several terraces of variable geometry and thickness (Pérez-González, 1971; Bárez and Pérez-González, 2006; Uribelarrea, 2008). The subsoil consists of Tertiary marl-gypsum evaporitic materials, which when dissolved and gave place to stacking and superposition of several terraces even thicker than $40 \mathrm{~m}$ (Pérez-González, 1971), giving place to the so-called Complex Terrace of Butarque (hereafter CTB), in the valley of the Manzanares river (Goy et al., 1989), and to the Complex Terrace of Arganda (hereafter CTA), in the river Jarama valley (Pérez-González, 1994).

CTB is probably made up by terraces at $+25-30 \mathrm{~m}$ and $+18-20 \mathrm{~m}$, which are sunken and the newest and the oldest overlay each other. Alluvial plain deposits dominate the CTB. These consist of sand bars which alternate with mud deposits associated with a flood plain (Carrillo et al., 1978; Silva, 2003). Four lithostratigraphic units have been identified in the CTA: Arganda I, II, III and IV (Pérez-González, 1980). The first three units could be related respectively to terraces $+30-32 \mathrm{~m},+23-24 \mathrm{~m} \mathrm{y}+18-20 \mathrm{~m}$ (PérezGonzález and Uribelarrea, 2002), whereas the last corresponds to lateral deposits to the Jarama river. Arganda I shows abundant flood plain deposits together with sand bars, whereas Arganda II and III consist mainly of gravel and sand bars, and to a lesser extent clayish-mud deposits (Pérez-González, 1980; Arche, 1983).

Paleolithic lithic industry has been identified in all facies of CTA and CTB. Additionally, macro-vertebrates have been identified in the sand bars; macro and micro mammals, molluscs, fish, amphibious, reptiles and birds have been recorded in the flood plain facies (Rubio-Jara et al., 2016), where pollen of the plant environment is well preserved (Manzano et al., 2010; Ruiz Zapata et al., 2017). The many sites excavated in the area have revealed some of the activities carried out by human groups during the Pleistocene in a fluvial environment (Santonja et al., 1980; Yravedra et al., 2010, 2012; Panera et al., 2014), as well as the surrounding plant landscape. Numerical dating (Panera et al., 2011) is consistent with the published biostratigraphic data (Sesé and Sevilla, 1996; Sesé and Soto, 2000). Both provide a strong chronological framework for the deposits of the valleys of the Manzanares and Jarama rivers between the second half of the Middle and the first third of the Later Pleistocene. Based on this data and with the purpose of establishing the structure and evolution of the plant landscape, the so-called pollen sequence JM-17 has been produced joining the partial sequences obtained from the archaeological sites identified in CTA and CTB.

\section{Materials and methods}

The following sites are associated with CTB: ETB (Estanque de Tormentas de Butarque), ECUL (Estación Depuradora de Aguas Residuales de la Cuenca Baja del Arroyo Culebro), ESTRG (Estragales) and PRERS (PRERESA) (Fig. 1). The evolutionary stage of Microtus brecciensis in site H02 of ETB (Laplana et al., 2015), dates this unit to the Middle Pleistocene, later than Valdocarros. ECUL has been dated to $133 \pm 28 \mathrm{ka}, 105 \pm 10 \mathrm{ka} \mathrm{BP}$ (Silva et al., 2013) by aminoacid racemisation (AAR) technique. The sample was taken from a molar of Equus sp-ESTRG has numerical dates obtained by luminiscence, one TL of $107+39 /-22 \mathrm{ka} \mathrm{BP}$ and another one OSL of de $122.1 \pm 11.1$ ka BP (Pérez-González et al., 2008). Lastly, in CTB, the site PRERS (PRERESA) provides an optically stimulated luminiscence (OSL) date of $84.1 \pm+5.6 \mathrm{ka}$ (Yravedra et al., 2012), which is consistent with the presence of Microtus cabrerae (Sesé et al., 2011), although the recently published data of ESR suggest that it could be earlier (Moreno et al., 2018).

Four sequences have been analysed in CTA; two in Arganda I (MQ-Ar1 and MQ-Ar1b sequences); one in the Valdocarros site (VALC) of Arganda II; and another one in HAT site of Arganda IV. Two dates obtained through AAR (Amino Acid Racemisation) together with the evolutionary stage of the recorded micromammals in the unit suggest that unit Arganda I was deposited in MIS 11 (Panera et al., 2011). In the Valdocarros site (VALC) of Arganda-II, the AAR analysis applied to two samples of two consecutive sequences provides dates of $262 \pm 68 \mathrm{ka}$ and $254 \pm 47$ $\mathrm{ka}$, respectively. These dates overlie each other along the period between $255 \mathrm{ka}$ and $269 \mathrm{ka}$ (Panera et al., 2011) and would match an interestadial at the end of MIS 9 or MIS 8, or early MIS 7 (Panera et al., 2011). Based on these dates and the climatic needs of the amphibian and reptile species retrieved from the four levels at the Valdocarros site, the two lower levels have been assigned to MIS 8 and the two upper ones to MIS 7 (Blain et al., 2012). With regard to Arganda-IV, the OSL dates indicate a beginning at $112 \pm+36-22 \mathrm{ka}$ 


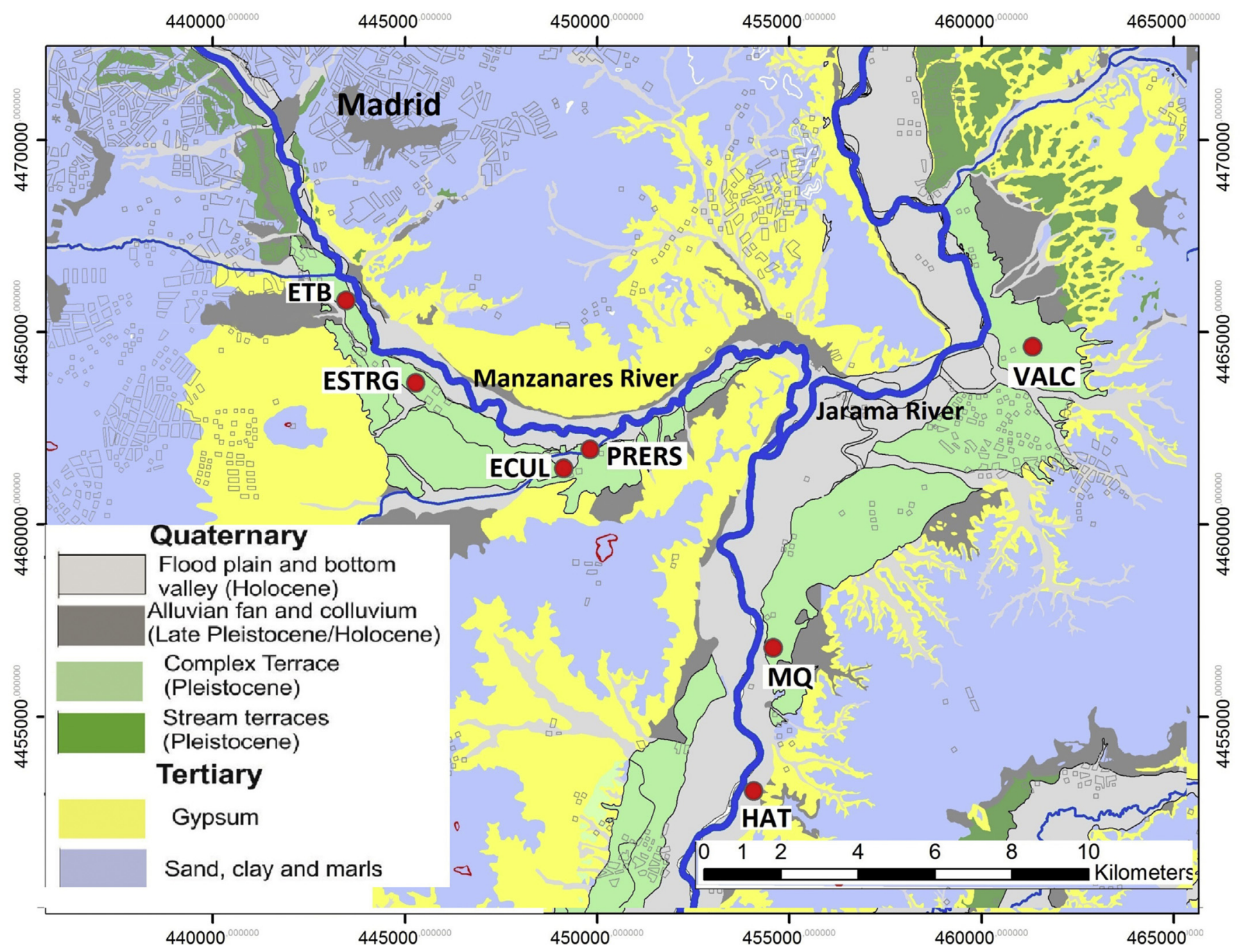

Fig. 1. Location of pollen samples at the Manzanares and Jarama valleys in Madrid (Spain).

and $85+ \pm 18-13 \mathrm{ka}$ (Torreblanca), $74 \pm 16 /-12.1 \mathrm{ka}$ in HAT site and $74 \pm 5 \mathrm{ka}$ in Maresa (Panera et al., 2005), however the pollen sequences were discovered to be sterile. Only the top of the HAT site (San Martín de la Vega), dating to $8 \pm 0.7 \mathrm{ka}$ (Holocene), provided a complete pollen sequence.

Sampling was carried out in open trenches, which had been previously cleaned from the lower to the upper area in order to avoid contamination. The extraction of the pollen grains was carried out according to standard policies (Coûteaux, 1977), consisting of a chemical attack to the soil using acids and alkalies. The resultant residue was treated with enrichment techniques with Thoulet solution (Goeury and de Beaulieu, 1979). The statistical treatment of the data was executed using the software packages TILIA and TILIA GRAPH (Grimm, 1987, 2004). The graphic representation, in this case, is shown through a bar chart or Pollen Histogram (Fig. 2). The establishment of pollen zones is based on an agglomerative division carried out with the CONISS method (Grimm, 1987). The distance between the samples of each sequence has been standardised, as well as the separation interval in each one of them. The percentage of the arboreal and non-arboreal taxa (bushes and herbaceous plants) has been calculated in relation to the base sum or total sum of the pollen. This sum enables the establishment, and therefore the comparison, of the relationship between AP (tree pollen) and NAP (bushes and herbaceous plant pollen), which define the structure of the vegetation for each sample. However, the percentages of aquatic taxa and spores have been calculated over the total sum, so these more local elements do not interfere in the reconstruction of the plant landscape. A Principal Components Analysis (PCA) was also executed in order to establish the relationship between the vegetation and its climatic (paleoenvironmental) implications. To this effect, the most significant taxa of the sequence JM-17 were chosen (Fig. 3). All these taxa, except Pinus and Cupressaceae, are shown grouped according to their ecological requirements; this is Mesophilic Forest, Mediterranean Forest and Steppe Plants. Finally, a synthetic representation of the pollen content of each sequence has been performed, relating it to the $\delta \mathrm{O}^{18}$ curve (Fig. 4).

\section{Results}

All the eight analysed sequences, except the ones from PRERS (CTB), are rich in well preserved pollen, and show more than reasonable values in taxonomic diversity.

The peculiarities and differences of each sequence (Table 1) highlights specific facts related to the plants dynamics. In sequence JM-17, a total 44 taxa have been identified, of which 12 are arboreal, three bushy and 29 herbaceous, together with eight aquatic elements, as well as monolete and trilete spores. The AP-NAP ratio 


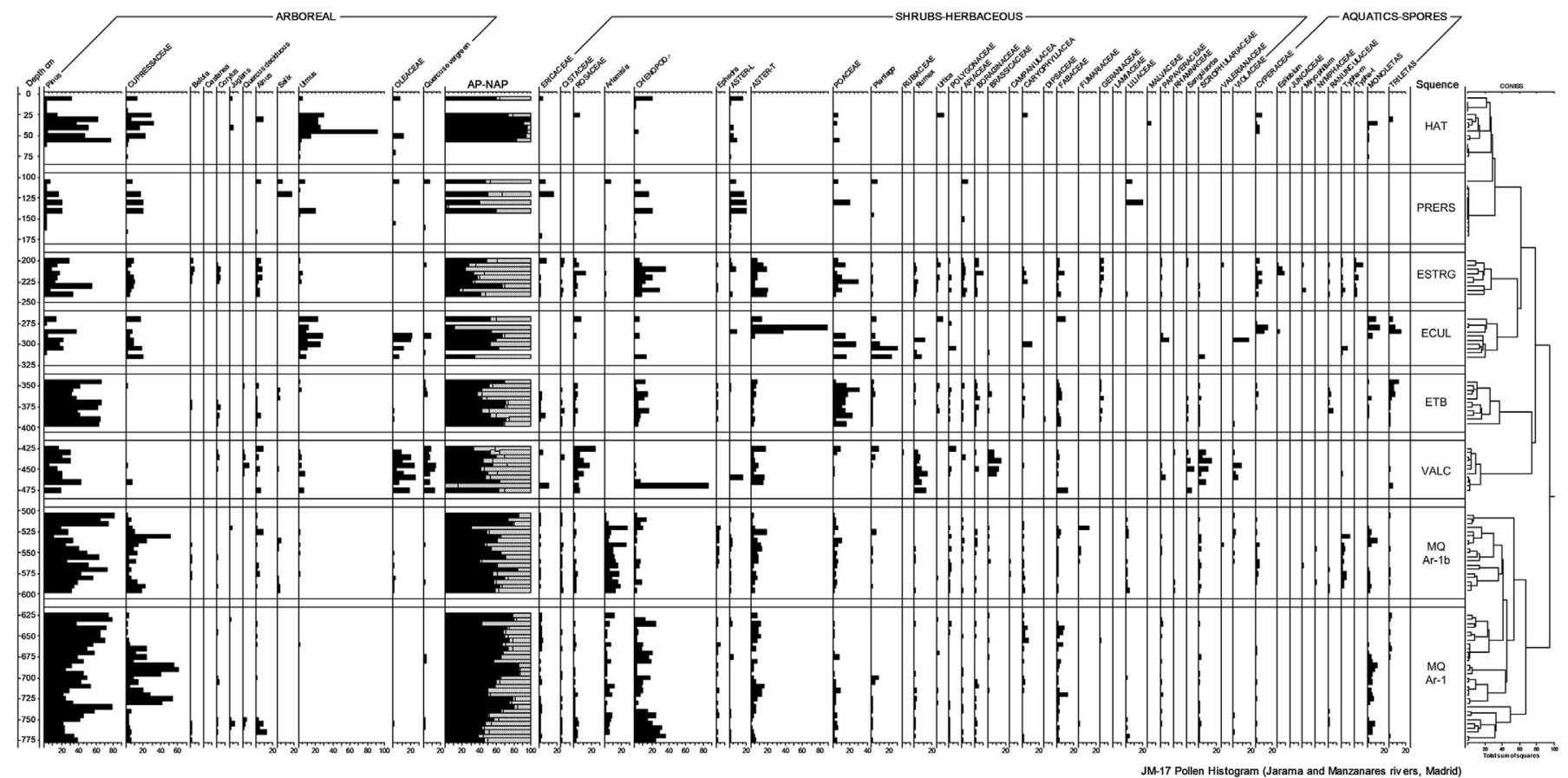

Fig. 2. Detailed pollen histogram of pollen samples.

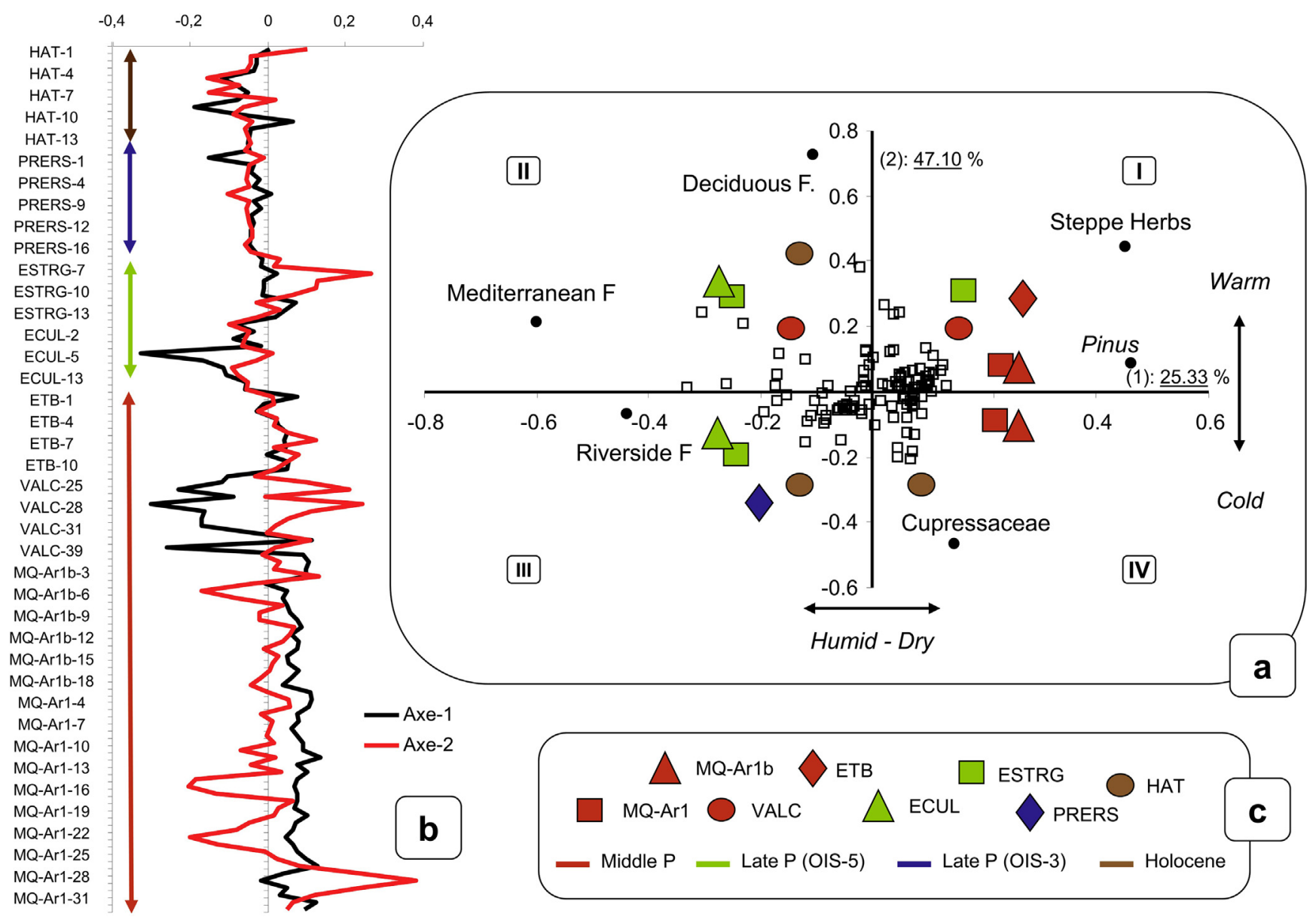

Fig. 3. ACP of the samples and selected pollen ensembles. 


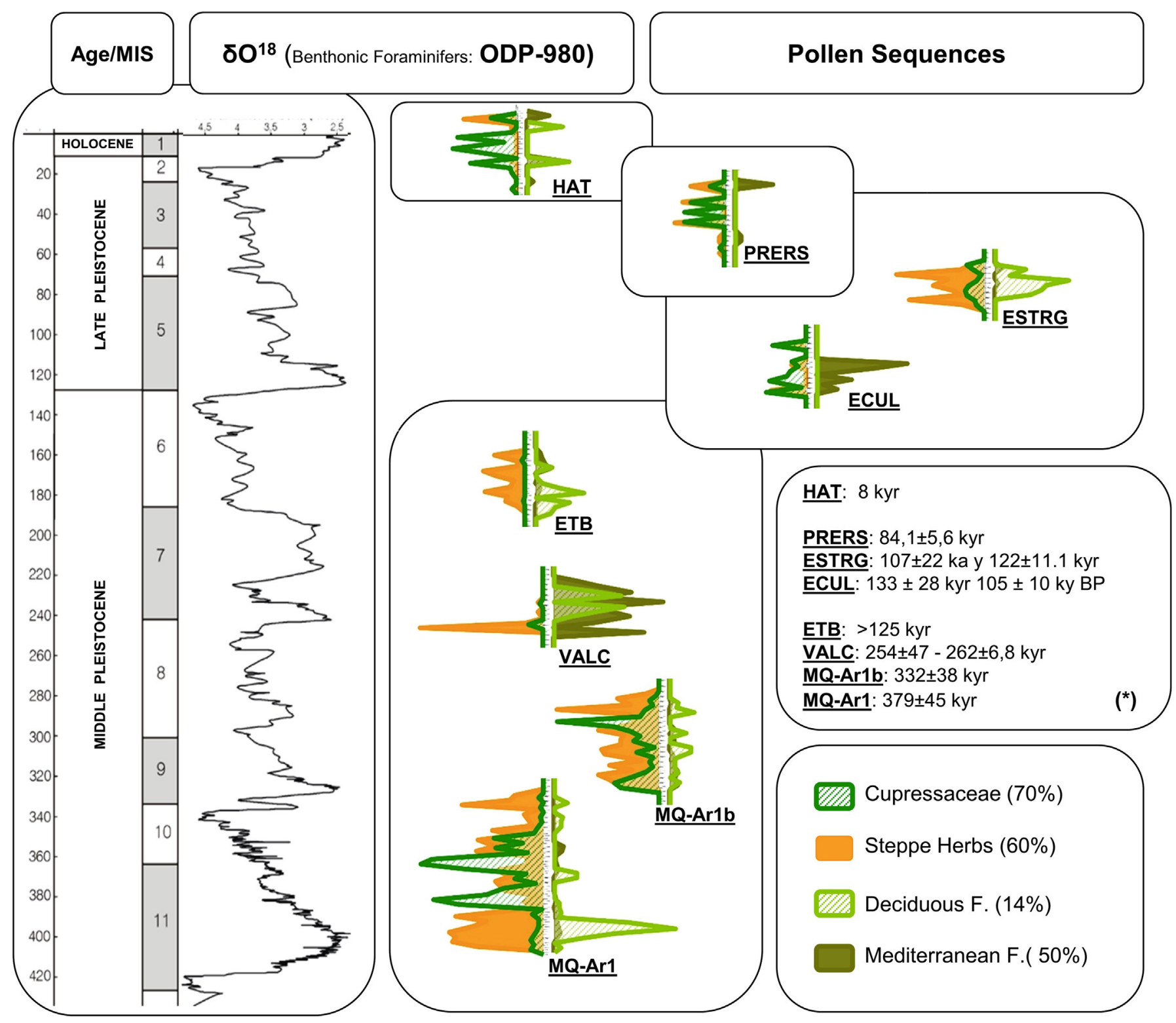

Fig. 4. Synthetic pollen diagram.

determines a clear superiority of the arboreal component, due to the development of the pine forests and to a lesser extent of the Cupressaceae; besides, the presence of a local forest has been identified, in general scarcely developed and constituted by Mediterranean taxa (evergreen type Quercus and Oleaceae), Mesophilic (Betula, Castanea, Corylus and evergreen type Quercus), as well as a riverside woodland (Alnus, Salix and Ulmus). The bushy stratum does not play a relevant role among the plants. The continuous presence of several types of thicket (Ericaceae, Rosaceae y Cistaceae) can be observed in all sequences. The herbaceous ensemble becomes occasionally dominant in part of some sequences or in the whole, as in ESTRG, although in general the ensemble shows a very similar composition, defined by the superiority of Asteraceae, Poaceae and Chenopodiaceae. The development of poaceae is remarkable in ESTRG, as well as in ETB. More specifically, the presence of Artemisia, Plantago and Rumex, together with a relatively varied ensemble of more ubiquitous taxa, is outstanding. Two large groups of herbaceous plants have been defined on the basis of the prevailing taxa: Xerophile (Asteraceae and Poaceae), and
Steppe (Artemisia, Chenopodiaceae and Ephedra), whose development responds to a higher or lower availability of water. The geological substrate is dominated by Terciary evaporitic materials (salina), which provides optimal conditions to the water and the environment for the development of gypsophile plants. This would explain the low levels of diversity detected in the pollen analysis, as well as the concentration of micromammals in these areas (Panera et al., 2014). Aquatic taxa (Cyperaceae, Epilobium, Juncaceae, Myryophillum, Nymphaceae, Ranunculaceae and Typha), are recorded in almost all sequences, although in low percentages, suggesting the presence of areas subject to accumulation of water associated with floodplain environments. They are absent in the VALC sequence, probably due to the fact that the analysed deposits were the result of the silting up of an abandoned meander. Nevertheless, in the case of the PRERS sequence, this lack of aquatic taxa could suggest certain shortages in the availability of liquid water, as is suggested by the low diversity of the floral landscape from the pollen content (Fig. 2).

The low representation of the Nitrophilous herbaceous 
Table 1

Synthetic pollen information of the JM-17 sequence.

\begin{tabular}{|c|c|}
\hline POLLEN/Vegetation & CLIMATE/Palaeoenvironment \\
\hline \multicolumn{2}{|l|}{ JM-17 sequence (Jarama and Manzanares fluvial plain, Madrid) } \\
\hline \multicolumn{2}{|c|}{44 taxa, (12 arboreal, 3 shrub and 29 herbaceous), 8 aquatic taxa and Spores } \\
\hline \multicolumn{2}{|l|}{ HAT: $(80 \mathrm{ka})$} \\
\hline AP increase (Pinus, Cupressaceae, Oleaceae and Ulmus) & Warm \\
\hline Asteraceae, Aquatic taxa. Decrease NAP diversity & Humid-Dry \\
\hline \multicolumn{2}{|l|}{ PRERS: $(84.1 \pm 5.6 \mathrm{ka})^{*}$} \\
\hline AP development (Pinus and Cupressaceae) & Cold-Humid/Dry \\
\hline Non Mesophile; River and Mediterraneand AP presences & Humid-Cool \\
\hline Dominance of Chenopodiaceae and Asteraceae. & Dry-Warm \\
\hline \multicolumn{2}{|l|}{ Non Nitrophilous and Aquatics } \\
\hline \multicolumn{2}{|l|}{ ESTRG: $(107 \pm 22 \mathrm{ka}$ and $122 \pm 11.1 \mathrm{ka})$} \\
\hline Lower values of AP; Increase, Mesophile and River taxa & Humid-Cold \\
\hline \multicolumn{2}{|l|}{ Non Mediterranean taxa. Highest diversity } \\
\hline \multicolumn{2}{|l|}{ Higher values of Chenopodiaceae, Asteraceae and Poaceae. } \\
\hline \multicolumn{2}{|l|}{ ECUL: $(133 \pm 28 \mathrm{ka}$ and $105 \pm 10 \mathrm{ka})$} \\
\hline Pinus decrease, Cupressaceae and Ulmus Increase & Humid-Cool \\
\hline \multicolumn{2}{|l|}{ Lower values of Mediterranean and No Mesophile AP. } \\
\hline \multicolumn{2}{|l|}{ Dominance of Asteraceae, Poaceae, Plantago and Aquatics } \\
\hline \multicolumn{2}{|l|}{ ETB: $(>125 \mathrm{ka})$} \\
\hline AP dominance (Pinus) & Dry \\
\hline Mesophile, Mediterranean and River AP presence & Warm \\
\hline \multicolumn{2}{|l|}{ Non Cupressaceae and Aquatics. } \\
\hline \multicolumn{2}{|l|}{ Dominance of Poaceae, Chenopodiacee, Asteraceae } \\
\hline \multicolumn{2}{|l|}{ Increase of herbaceous diversity } \\
\hline \multicolumn{2}{|l|}{ VALC: $(254 \mathrm{ka})$} \\
\hline Regression of Pinus, Non Cupressaceae & Warm \\
\hline Dominance of Mediterranean forest, Rosaceae and Rumex & Humid-Dry \\
\hline \multicolumn{2}{|l|}{ Highest diversity } \\
\hline \multicolumn{2}{|l|}{ MQ-Ar1b: $(332 \pm 38 \mathrm{ka})$} \\
\hline AP (Pinus - Cupressaceae) decrease & Humid \\
\hline Increase River forest and Aquatic plants & Warm-Cold \\
\hline \multicolumn{2}{|l|}{ Dominance of Artemisia and Asteraceae } \\
\hline \multicolumn{2}{|l|}{ MQ-Ar1: $(379 \pm 45 \mathrm{ka})$} \\
\hline Increase of $\mathrm{AP}$ & Warm \\
\hline Pinus - Cupressaceae dominant. Decrease of AP Mesophilous & Humid-Dry \\
\hline Chenopodiaceae & \\
\hline
\end{tabular}

assemblage (Plantago, Rubiaceae, Rumex, Urtica and Polygonaceae) is outstanding, taking into consideration that the palaeontological record of the sequences reveals the presence and nature of elements responsible for providing the soil with nitrogen (Rubio-Jara et al., 2016, Sesé and Soto, 2000, 2011). Finally, of note is the uneven development, both quantitatively and qualitatively, of the ubiquitous herbaceous plants, virtually absent in PRERS and HAT sequences, as their diversity could point to the establishment of few adverse conditions.

Assessing the sequence as a whole, the development of the pine forest and its switch to Cupressaceae is remarkable, as well as its higher representation in the MQ-Ar1, MQ-Ar1b and HAT sequences. Lower percentages are shown in the ECUL, ESTRAG and PRERS sequences, whereas in VALC and ETB, Cupressaceae are virtually absent. The development of the local forest, Mesophile, can be seen in the MQ-Ar1, MQ-Ar1b, VALC, ETB and ESTRG sequences, whereas it is absent in ECUL, PRERS and HAT. On the contrary, the Mediterranean forest becomes especially important in VALC and ECUL, and from this moment on it starts to dominate the Mesophile forest. Altogether, the composition reveals the establishment of
Mediterranean conditions, with fluctuation in temperature and humidity rates. This is defined by the development of the riverside woodland and to a lesser extent by the development of the aquatic taxa.

An ACP with all the samples has been carried out in order to establish the pattern of the changes which occurred. Pinus and Cupressaceae have been added to the analysis because of their representation in the landscape and the ensembles that define the local Mesophile, Mediterranean and Riverside forests. Six components have been obtained (Fig. 3), of which the first two explain $47.10 \%$ of the data variability, and have turned out to be highly significant when grouping the samples, in each quadrant defined by one specific flower group. From the data extracted, it can be summarised that the component 1 discriminates according to the humidity rate (low on positive values and high on negative ones), as opposed to component 2 , whose discrimination is based mainly on temperature (warmer on positive values than on negative ones). Thus, each quadrant implies certain climatic conditions, which are defined by the samples (Fig. 3a). In order to show the weight of each component on the samples, the values of such weight along 
the total sequence obtained has been represented through curves (Fig. 3b), making it easier to locate each sample, which is identified by the positive or negative value of each component within its quadrant, and allows to delete the number in the original graphic.

On another note, each sequence has been identified with a colour and a geometric figure, which refers to its age. The quadrant or quadrants where the samples of each profile are located are identified with the appropriate symbol (Fig. 3c). Thus, with the global distribution of the samples of each sequence in the quadrants, the evolution of the prevailing conditions has been determined from a climatic point of view. It has been stated that during the oldest Middle Pleistocene identified in the area (MIS 11-9), the samples of sequences MQ-Ar1 and MQ-Ar1b fluctuate in both cases over the positive values of component 1 : this is to say, under drier conditions. However, with regards to component 2 , the location is distributed between positive and negative values, which points to a transition from initial warm conditions to a later cooling in sequence MQ-Ar1. Afterwards, a new rise in temperature is observed in sequence MQ-Ar1b.

The samples from the VALC sequence, which has been defined as an interestadial within the cold stage MIS- 8 or MIS 8/7 transition (Blain et al., 2012), fluctuate between positive and negative values of component 1 . In other words, fluctuations in the humidity rate are shown. However, all fluctuations are located within positive values in component 2 , which reveals warm conditions. This also proves the identification of quadrant (II) as the nearest climate optimal stadium.

All samples from the ETB sequence (Complex Terrace of Butarque), dated to the Middle Pleistocene, are located within quadrant (I), which relates to a progressive loss of humidity.

The ECUL sequence, dating to the Late Pleistocene, is located within quadrants II and III, and, as well as ESTRG, is also present in quadrant I. This occurred in response to a great humidity, which evolved towards warmer and drier conditions, inheriting the model defined to the end of the Middle Pleistocene and trending towards $80 \mathrm{ka}$. This is reflected in the PRERS sequence, given that its samples are located within quadrant III, characterised by humid cold, to the end of MIS-5. The Holocene (HAT) is distributed in quadrants II, III and IV. It is consistent with the temporal order that proves the transition to relatively drier conditions.

Finally, the paleoenvironmental and paleoclimatic changes which occurred in the JM-17 sequence, during the Middle and Late Pleistocene, are assessed in more detail. The representation of the percentage data of Cupressaceae, as well as the ensembles of steppe plants, and Mesophile and Mediterranean forests has been used for this purpose, expressed through curves and arranged by pairs (Fig. 4). The same graphic scale has been kept for all figures. This scale expresses the maximum percentage reached, thus raising the weight and leaving the numeric value unaltered. These curves are then compared with the $\delta \mathrm{O}^{18}$ curve of the benthic foraminifers from the North Atlantic drilling ODP-980 (from the NOAA Paleoclimatology Program, and McManus et al. (1999), in order to establish the relationship between plant landscape and climate).

Thus, we have a relatively dry environment, warm or cool, dominated by steppe plants alternating with Cupressaceae. However, in the early MQ-Ar1 sequence, fluctuations in the vegetation due to climatic variations can be observed. At first, the development of Betula, Quercus decidious and Alnus reveal warm conditions. Later these three taxa retreat and disappear, while a simultaneous rise in the levels of Cupressaceae suggests colder conditions. Later, a rise in temperature allows a limited development of Oleaceae. A similar spectrum can be seen in the MQ-Ar1b sequence $(332 \pm 38$ $\mathrm{ka})$, however on this occasion the percentages of steppe plants and Cupressaceae are not too high. This proves that conditions were not extreme, and the presence of Mesophile forest was constant.
Circa $254 \pm 47-262 \pm 6.8 \mathrm{ka}$ (VALC), the pollen spectrum shows an important shift in the development and makeup of the plant assemblage, firstly materialised by a remarkable drop of the pine forest (Fig. 2) and the development of steppe plants (Figs. 2 and 4), during the end of MIS 8. Afterwards, an expansion of a local type of forest takes place. Mediterranean elements thrive in this forest, Oleaceae and Quercus evergreen, and alternate with Mesophile elements. The expansion of the deciduous Quercus (which reaches the maximum value of the whole sequence) stands out as result of the establishment of warmer and relatively humid conditions, probably related to MIS 7 .

Before $125 \mathrm{ka}$ (ETB), the plant landscape follows a pattern similar to that of the earlier sequence, although steppe plants spread and dominate. A regression of the forests can be observed and taxa such as Cupressaceae, Quercus decidious, Oleaceae and Quercus evergreen even disappear, pointing to a drop in temperature. The Mediterranean forest then starts spreading due to the temperature drop, as it is recorded only in the upper part of the sequence. This sequence is found in MIS- 6 and reflects the response of the plants to a considerably cold short event.

The sequences of the Late Pleistocene are characterised by a remarkable climatic variability, defined by fluctuations of warm, dry/humid and colder phases. They begin in the ECUL sequence $(133 \pm 28 \mathrm{ka} 105 \pm 10 \mathrm{ka})$ with the presence of Cupressaceae and Mediterranean forest, together with a virtual lack of Mesophile forest, although Ulmus is identified. This is to say, the floral composition and the dominant taxa percentages seem to be far from what should be expected in an interglacial period such as MIS 5. Additionally, steppe plants are well developed, which confirms the drop in the humidity rate.

The humidity rate recovers during the ESTRG sequence $(107 \pm 22 \mathrm{ka}$ and $122 \pm 11.1 \mathrm{ka})$, whose pollen spectrum is characterised by the expansion of the Mesophile forest. However, Quercus decidious is not found, there is a drop of Cupressaceae and aquatic taxa experience a greater development. This recovery is disrupted in the PRERS sequence $(84.1 \pm 5.6 \mathrm{ka})$, whose pollen spectrum is characterised by the fluctuations of Xeric plants and Cupressaceae, as well as by an almost total absence of local forest. Furthermore, the lower percentages of Pinus, as well as the lower diversity, reveal the establishment of cold and dry conditions. This is the trend $c .80$ $\mathrm{ka}$, as is represented in the PRERS sequence by humid cold conditions to the end of MIS-5. Finally, the HAT sequence (Holocene) reflects the transition from a warm-humid-cool climate to a warm and dry one, indicating the establishment of Mediterranean conditions in the area.

\section{Discussion}

The sequences represented in this chronological framework fulfil the global standards concerning the higher or lower development of the tree component in relation to the type of isotopic stadium, whether odd or even. Its composition fits with the characteristics of the latitude band where the sequences are located, as well as with the strong continental nature of the study area. In this respect, the composition, evolution and pattern of the landscape changes show a strong parallelism with works carried out in the past over deposits equally associated with fluvial environments in nearby areas. Thus, in the Middle Pleistocene, the archaeological site of Ambrona (Ruiz Zapata et al., 2005; Pérez-González, 1994), probably dating to MIS-11 (Falguères et al., 2006), shows a clear dominance of tree plants, due to the expansion of the pine forest together with local forest, mainly Mesophile, whose pattern is very similar to that identified during the MQ-Ar1 and MQ-Ar1b sequences. This data is also consistent with that obtained from the sea drill MD01-2447, from the NW of the Iberian Peninsula (Desprat 
et al., 2005). Although the four phases have not been identified, there are records of an initial warming phase where birch type, oak and alder trees develop, followed by a later drop in temperature which caused the above tree taxa to grow backwards in the MQ-Ar1 sequence (fluvial sequence Arganda I at Jarama). The expansion of Mediterranean plants which is recorded subsequently in the MQAr1b sequence (fluvial sequence Arganda I at Jarama), would relate to a temperature rise during the summer, linked to the start of a climatic optimum. The pollen spectrum of the VALC sequence (fluvial sequence Arganda II at Jarama), whose prevailing characteristic is the lower representation of pine forest associated with the higher presence of Mediterranean forest, shows great similarities with the spectra of the pollen sequences from the Tagus valley (Toledo), clearly related to zones I-II of the Pinedo sequence (Martín Arroyo, 1998; Martín Arroyo et al., 2000; Ruiz Zapata et al., 2004), and GI/II of Galería (Atapuerca, García Antón and Sainz Ollero, 1991; Rodríguez et al., 2011). The development of Quercus decidious together with that of the Mediterranean forest, which reaches the highest ratio, reveals that this forest stage is the warmest period of MIS 9 in central Iberia. Such forest expansion and climatic improvement identified during MIS 9 are commonly recognized in the pollen sequences from Southern Europe, such as Tenaghi Philippon (Tzedakis et al., 2003; Wijmstra and Smit, 1976) and Praclaux (Reille and de Beaulieu, 1995; Reille et al., 2000), as well as in the pollen record from the SW Iberian margin MD01-2443 (Tzedakis et al., 2003b; Roucoux et al., 2006), MD03-2697 (Desprat et al., 2009) and MD99-2331 (Naughton et al., 2007, 2009).

With regard to the Middle Pleistocene, there is information for MIS 6 in the ETB sequence (CTB). According to this a substantial regression of the forest occurs, pointing to a noteworthy cold event. Our data is consistent with what has been observed in central Spain (Blain et al., 2012, 2017; Laplana et al., 2015).

With regard to the Late Pleistocene, there is data for the MIS 5 in the ECUL sequence (Butarque Complex Terrace) which shows the development of Mediterranean and steppe taxa. This suggests that this is not a temperature and humidity optimum, as the plant model of this area is not consistent with the prevalence of deciduous plants recorded in the European sequences, but with the expansion of the Mediterranean taxa associated with termophile coastal areas of the southern Iberian Peninsula (Carrion, 1992; Fernández et al., 2007). Oaks are also absent in the ESTRAG sequence (Butarque Complex Terrace), in which a rise in humidity is recorded, as well as a slight rise of Mesophile taxa. Final MIS 5 has been recorded in the PRERS sequence (Butarque Complex Terrace), where tree taxa suffer a general regression, which suggests cold and dry conditions. Obviously, this plant ensemble and its percentages is not consistent with models known so far in the European pollen sequences for Eemiense or MIS 5e (Follieri et al., 1988; Pons and Reille, 1988; Sánchez-Goñi et al., 1999; Tzedakis et al., 2003; Müller et al., 2003). In any case, Mediterranean climatic areas with such a strong continental influence as our research area are unknown in the rest of Europe.

Therefore, the Late Pleistocene sets a transition from a Mediterranean to a Mesophile forest with little pine forest, similar to the one defined in zone IV of the Pinedo sequence (Martín Arroyo et al., 2000; Ruiz Zapata et al., 2004), as well as in the Camino pollen sequence (Pinilla del Valle) (Arsuaga et al., 2012). In the Pinilla del Valle sequence, a progressive loss (both qualitative and quantitative) of the forest cover is recorded, as well as the presence of xerophyte taxa and a gradual loss of nitrophilus plants, becoming similar to the PRERS spectra.

A continental Mediterranean regime can be established as the dominant one in the centre of the Iberian Peninsula. It responds to the climatic optimal with greater development of the local forest, usually with Mediterranean characteristics, and also of aquatic and riverside woodlands. In areas with higher humidity rates such as the north of the Peninsula and northern Europe, plants show similar evolution structures. The European ensembles cannot be compared to those recorded in the centre of the Iberian Peninsula because their geographic locations imply important differences both in bioclimatic terms and in plant composition. These landscapes with lower diversity are those where human groups of the second half of the Middle and first third of the Late Pleistocene find the necessary resources for their survival.

\section{Conclusions}

The results obtained from the Manzanares and Jarama rivers sequences point to a high pollen variability during c. 379,000 years of paleoenvironmental history of the area. In general, the data recorded so far is consistent with the climatic changes recorded to millenial/multimillenial scale, although some local and/or regional particularities exist.

In general, the following conclusions can be stated with regard to the variation of landscapes, climatic implications and resources:

- Pinus and Cupressaceae are the main elements of the regional landscape, together with a local forest, whether Mesophile or Mediterranean, depending on temperature and humidity rate.

- The behaviour of the aquatic and riverside taxa, in relation to the availability of liquid water, is used to determine fluctuations in the humidity rate.

- The peculiarities of each period studied can be summarised as a higher development of the mesophile forest during the Middle Pleistocene, which gives place to a prevalent Mediterranean forest during the Late Pleistocene.

- The reconstruction of landscape and resources shows:

o The existence of a fluvial environment according to the development of the riverside woodlands.

o The greater or lesser permanence of marsh areas according to the development of aquatic taxa.

o Taxa traditionally associated with certain dryness (steppe) can sometimes respond to conditions given by the quality of the water regarding salinity.

o Presence of lithic industry indicates proximity of human settlement.

- The climatic variability of MIS 11 has been identified as an initial warmer period followed by a colder one and a subsequent warmer period in the MQ-Ar1 and MQ-Ar1b sequences (Arganda I in ACT).

- The VALC sequence (Arganda II, in ACT) provides a reconstruction of the plant changes during MIS 8-7. The shift period between both stadia has been recorded by the substitution of xeric herbaceous plants for a local forest associated with a climatic optimum, probably MIS 7.

- A period of intense cold has been recorded in the ETB sequence (Complex Terrace of Butarque). There is a clear regression of the forest, and some taxa such as oak, Holm oak and Oleaceae even disappear.

- The plant model of our study area during MIS 5 responds to an expansion of the Mediterranean taxa, associated with thermophilic coastal areas of the southern Iberian Peninsula for the ECUL sequence, slightly more humid in the ESTRAG sequence and colder and drier in the PRERS sequence.

- Finally, the Holocene starts with an abrupt change to the plant environment, showing regression of the mesophile taxa and lower diversity. This is not the expected response of the vegetation for this period, suggesting that no-climatic factors, such as cattle grazing, could be responsible for this situation. 


\section{Acknowledgements}

This research has been funded by the Dirección General de Patrimonio Histórico (PR170/04-13244; PR42/05-14071; 1962/ 2006/00) and the Dirección General de Investigación of the Comunidad de Madrid (06/123/2003). We are grateful to J.S. Carrión and an anonymous reviewer for making constructive comments, and to Marta Muñiz and Ciara Travis for English editing.

\section{References}

Arche, A., 1983. Coarse-grained meander lobe deposits in the Jarama river, Madrid, Spain. In: Collinson, J.D., Lewin, J. (Eds.), Meander and Ancient Fluvial Systems. International Association Sedimentology, pp. 313-321 (Special Publication 6).

Arsuaga, J.L., Baquedano, E., Pérez-González, A., Sala, N., Quam, R.M., Rodríguez, L., García, R., García, N., Álvarez, D., Laplana, C., Huguet, R., Sevilla, P., Maldonado, E., Blain, H.A., Ruiz-Zapata, B., Sala, P., Gil-García, M.J., Uzquiano, P. Pantoja, A., Márquez, B., 2012. Understanding the ancient habitats of the lastinterglacial (late MIS 5) Neanderthals of central Iberia: paleoenvironmental and taphonomic evidence from the cueva del Camino (Spain). Quat. Int. 275, 55-75.

Baena, J., Conde, C., Gamazo, M., Sesé, C., Soto, E., 2002. Repertorio de yacimientos paleolíticos en el Manzanares y Jarama. In: Panera, J., Rubio-Jara, S. (Eds.), Bifaces y elefantes. La investigación del Paleolítico Inferior en Madrid. Museo Arqueológico Regional de la Comunidad de Madrid, Zona Arqueológica 1, pp. 461-491.

Bárez, S., Pérez-González, A., 2006. Terrazas fluviales del Pleistoceno inferior y medio del río Manzanares en Vaciamadrid: el perfil de Calamuecos y sus implicaciones geomorfológicas. Bol. Geol. Miner. 117 (3), 351-361.

Battarbee, R.W., Gasse, F., Stickley, C.E., 2004. Past Climate Variability through Europe and Africa, vol. 6. Kluwer Academic Pub.

Benito, G., Macklin, M.G., Zielhofer, C., Jones, A.F., Machado, M.J., 2015. Holocene flooding and climate change in the Mediterranean. Catena 130, 13-33. Past Hydrological Extreme Events in a Changing Climate.

Blain, H.A., Panera, J., Uribelarrea, D., Rubio-Jara, S., Pérez-González, A., 2012 Characterization of a rapid climate shift at the MIS 8/7 transition in central Spain (Valdocarros II, autonomous region of Madrid) by means of the herpetological assemblages. Quat. Sci. Rev. 47, 73-81.

Blain, H.A., Rubio-Jara, S., Panera, J., Uribelarrea, D., Laplana, C., Herráez, E., Alfredo Pérez-González, A., 2017. A new middle Pleistocene (Marine oxygen isotope stage 6) cold herpetofaunal assemblage from the central iberian Peninsula (Manzanares valley, Madrid). Quat. Res. 87, 499-515.

Carrillo, L., Gisbert, J., Arche, A., 1978. Modelo de sedimentación de la terraza baja (T+18-20) del río Manzanares. Estud. Geol. 34, 549-552.

Carrion, J.S., 1992. Late quaternary pollen sequence from Carihuela Cave, southern Spain. Rev. Palaeobot. Palynol. 71, 37-46.

Coûteaux, M., 1977. A propos de l'interpretation des analyses polliniques de sediments minéraux principalement archeologiques on le milieu végétal, les faunes et l'homme. Supplément Bulletin Association Francaise Estudes Quaternaire 47, 259-276.

Crowley, T.J., Hyde, W.T., 2008. Transient nature of late Pleistocene climate variability. Nature 456 (7219), 226-230.

deMenocal, P., Ortiz, J., Guilderson, T., Sarnthein, M., 2000. Coherent high-and lowlatitude climate variability during the Holocene warm period. Science 288 (5474), 2198.

Desprat, S., Sanchez Goñi, M.F., McManus, J.F., Duprat, J., Cortijo, E., 2009. Millennial-scale climatic variability between 340000 and 270000 years ago in SW Europe: evidence from a NW Iberian margin pollen sequence. Clim. Past 5 , $53-72$.

Desprat, S., Sanchez Goñi, M.F., Turon, J.L., McManus, J.F., Loutred, M.F., Duprat, J. Malaize, B., Peyrone, O., Peypouquet, J.-P., 2005. Is vegetation responsible for glacial inception during periods of muted insolation changes? Quat. Sci. Rev. 24, $1361-1374$

Duplessy, J.C., Cortijo, E., Masson-Delmotte, V., Paillard, D., 2005. Reconstructing the variability of the climate system: facts and theories. Compt. Rendus Geosci. 337 (10-11), 888-896.

Falguères, C., Bahain, J.J., Pérez-González, A., Mercier, N., Santonja, M., Dolo, J.M. 2006. The Lower Acheulian site of Ambrona, Soria (Spain): ages derived from a combined ESR/U-series model. J. Archaeol. Sci. 33 (2), 149-157.

Fernández, S., Fuentes, N., Carrión, J.S., González-Sampériz, P., Montoya, E., Gil, G., Vega-Toscano, G., Riquelme, J.A., 2007. The Holocene and Upper Pleistocene pollen sequence of Carihuela Cave, southern Spain. Geobios 40, 75-90.

Fletcher, W.J., Sánchez Goñi, M.F., 2008. Orbital- and sub-orbital-scale climate impacts on vegetation of the western Mediterranean basin over the last 48,000 yr. Quat. Res. 70 (3), 451-464.

Follieri, M., Magri, D., Sadori, L., 1988. A 250,000-year pollen record from Valle di Castiglione (Roma). Pollen Spores 30, 329-356.

García Antón, M., Sainz Ollero, H., 1991. Pollen record from the middle Pleistocene Atapuerca site (Burgos, Spain). Palaeogeogr. Palaeoclimatol. Palaeoecol. 85 $199-206$.

Goeury, Cl., de Beaulieu, J.L., 1979. À propos de la concentration du pollen à l'aide de la liquier de Thoulet dans les sédiments minéraux. Pollen Spores 21, 239-251. Goosse, H., Renssen, H., Timmermann, A., Bradley, R.S., 2005. Internal and forced climate variability during the last millennium: a model-data comparison using ensemble simulations. Quat. Sci. Rev. 24 (12-13), 1345-1360.

Goy, J.L., Pérez-González, A., Zazo, C., 1989. Cartografía y Memoria del Cuaternario y Geomorfología, Hoja de Madrid (559). Mapa Geol. Espana - Escala 1:50 000, $2^{\mathrm{a}}$ Serie (MAGNA). IGME. Servicio, 71 pp.

Grimm, E.C., 1987. CONISS: a FORTRAN 77 program for stratigraphically constrained cluster analysis by the method of incremental sum of squares. Comput. Geosci. 13 (1), 13-35.

Grimm, E.C., 2004. TILIA and TILIA-GRAPH: pollen spreadsheet and graphics programs. In: 8th International Palynological Congress. Aix-en-Provence.

Köhler, P., Bintanja, R., Fischer, H., Joos, F., Knutti, R., Lohmann, G., MassonDelmotte, V., 2010. What caused Earth's temperature variations during the last 800,000 years? Data-based evidence on radiative forcing and constraints on climate sensitivity. Ouat. Sci. Rev. 29 (1-2), 129-145.

Laplana, C., Herráez, E., Yravedra, J., Bárez, S., Rubio-Jara, S., Panera, J., Rus, I., PérezGonzález, A., 2015. Biocronología de la Terraza Compleja de Butarque del río Manzanares en el Estanque de Tormentas al sur de Madrid (España). Estud. Geol. 71 (1) e028. https://doi.org/10.3989/egeol.41808.338.

Lézine, A.M., Von Grafenstein, U., Andersen, N., Belmecheri, S., Bordon, A., Caron, B., Cazet, J.P., Erlenkeuser, H., Fouache, E., Grenier, C., Huntsman-Mapila, P., Hureau-Mazaudier, D., Manelli, D., Mazaud, A., Robert, C., Sulpizio, R., Tiercelin, J.J., Zanchetta, G., Zeqollari, Z., 2010. Lake Ohrid, Albania, provides an exceptional multi-proxy record of environmental changes during the last glacialinterglacial cycle. Palaeogeogr. Palaeoclimatol. Palaeoecol. 287, 116-127.

Manzano, L., Expósito, A., Pérez-González, A., Soto, E. Sesé, C., Yravedra, J., RuizZapata, B., Millán, A., Benéitez, P., Torres, T., Mondéjar, J.A., Zarco, E., Sánchez, H., Citores, A., Ramos, M., Rodríguez, A., Citores, A., Ramos, M., Rodríguez, A., 2010. El yacimiento arqueo-paleontológico de E.D.A.R. CULEBRO 1 (Estación Depuradora de Aguas Residuales de la Cuenca Baja del Arroyo Culebro. In: Ministerio de Medio Ambiente, Confederación Hidrógráfica del Tajo (Eds.), Actas de las V jornadas de patrimonio arqueológico en la Comunidad de Madrid. Celebradas en el Museo Arqueológico Regional de la Comunidad de Madrid del 12-14 de noviembre de 2008. Alcalá de Henares. Madrid, pp. 203-214.

McManus, J.F., Oppo, D.W., Cullen, J.L., 1999. A 0.5- million-year record of millennial scale climate variability in the North Atlantic. Science 283, 971-975.

Margari, V., Skinner, L.C., Tzedakis, P.C., Ganopolski, A., Vautravers, M., Shackleton, N.J., 2010. The nature of millennial-scale climate variability during the past two glacial periods. Nat. Geosci. 3 (2), 127-131.

Martín-Arroyo, T., 1998. Paleoclimatología y paleoambiente durante el Pleistoceno Medio y Superior en el valle del Tajo. PhD Thesis. Universidad de Alcalá de Henares, Madrid.

Martín Arroyo, T., Ruiz Zapata, M.B., Pérez-González, A., Dorado Valiño, M., Valdeolmillos Rodríguez, A., Gil García, M.J., 2000. Registro paleoclimático del Pleistoceno Medio en el valle del río Tajo. Geotemas 1 (4), 259-262.

Mayewski, P.A., Rohling, E.E., Curt Stager, J., Karlen, W., Maasch, K.A., David Meeker, L., Meyerson, E.A., 2004. Holocene climate variability. Quat. Res. 62 (3), $243-255$

Mitchell, J.M., 1976. An overview of climatic variability and its causal mechanisms. Quat. Res. 6 (4), 481-493.

Moreno, D., Duval, M., Rubio-Jara, S., Panera, J., Bahain, J.J., Shao, Q., PérezGonzález, A., Falguères, C., 2018. ESR dating of Middle Pleistocene archaeopaleontological sites from the Manzanares and Jarama river valleys (Madrid basin, Spain). Quat. Int. (in press) https://doi.org/10.1016/j.quaint.2017.09.003.

Müller, U.C., Jo, P., Bibus, E., 2003. Vegetation response to rapid climate change in Central Europe during the past 140,000 yr based on evidence from the Furamoos pollen record. Quat. Res. 59, 235-245.

Naughton, F., Sanchez Goni, M.F., Desprat, S., Turon, J.-L., Duprat, J., Malaize, B., Joli, C., Cortijo, E., Drago, T., Freitas, M.C., 2007. Present-day and past (last 25000 years) marine pollen signal off western Iberia, Mar. Micropaleontology 62, 91-114.

Naughton, F., Sánchez Goñi, M.F., Kageyama, M., Bard, E., Duprat, J., Cortijo, E., Desprat, S., 2009. Wet to dry climatic trend in north-western Iberia within Heinrich events. Earth Planet Sci. Lett. 284, 329-342.

Nederbragt, A.J., Thurow, J., 2005. Geographic coherence of millennial-scale climate cycles during the Holocene. Palaeogeogr. Palaeoclimatol. Palaeoecol. 221 (3-4), 313-324.

Panera, J., Pérez-González, A., Rubio-Jara, S., Sesé, C., 2005. El yacimiento paleolítico de HAT en el valle del Jarama: una aportación de Cuaternario de la cuenca de Madrid al debate sobre el inicio del Paleolítico medio. In: Santonja, M., PérezGonzález, A., Machado, M.J. (Eds.), Geoarqueología y Patrimonio en la Península Ibérica y el entorno Mediterráneo. ADEMA, Soria, pp. 251-260.

Panera, J., Rubio-Jara, S., Pérez-González, A., Rus Pérez, I., Yravedra Sainz de los Terreros, J., Uribelarrea, D., Ruiz-Zapata, B., Sesé Benito, C., Soto, E., Farjas, M., Torres, T., Ortiz Menéndez, J.E., 2010. El registro Paleolítico de las terrazas complejas de los valles del Manzanares y Jarama. Actas de las quintas Jornadas del Patrimonio Arqueológico en la Comunidad de Madrid. In: Los primeros pobladores: Arqueología del Pleistoceno. Museo Arqueológico Regional de la Comunidad de Madrid, Alcalá de Henares, pp. 73-92, 2008.

Panera, J., Rubio-Jara, S., Yravedra, J., Hugues-Alexandre, B., Sesé, C., PérezGonzález, A., 2014. Manzanares valley (Madrid, Spain): a good country for Proboscideans and Neanderthals. Quat. Int. 326-327, 329-343.

Panera, J., Torres, T., Pérez-González, A., Ortiz, J.E., Rubio-Jara, S., Uribelarrea, D., 2011. Geocronología de la Terraza Compleja de Arganda en el valle del río 
Jarama (Madrid, España). Estud. Geol. 67 (2), 495-504.

Pérez-González, A., 1971. Estudio de los procesos de hundimiento en el valle del río Jarama y sus terrazas (nota preliminar). Estud. Geol. XXVII (4), 317-324.

Pérez-González, A., 1980. Geología y estratigrafía de los yacimientos de Áridos en la llanura aluvial de Arganda (Madrid). In: Santonja, M., López, N., PérezGonzález, A. (Eds.), Ocupaciones achelenses en el valle del Jarama. Arqueología y Paleontología, I. Diputación Provincial de Madrid, pp. 49-61.

Pérez-González, A., 1994. Depresión del Tajo. In: Elorza Gutiérrez, M. (Ed.), Geomorfología de España, Rueda, pp. 389-436.

Pérez-González, A., Rubio-Jara, S., Panera, J., Uribelarrea, D., 2008. Geocronología de la sucesión arqueoestratigráfica de Los Estragales en la Terraza Compleja de Butarque (Valle del río Manzanares, Madrid). Geogaceta 45, 39-42.

Pérez-González, A., Uribelarrea, D., 2002. Geología del Cuaternario de los valles fluviales del Jarama y Manzanares en las proximidades de Madrid. In: Panera, J., Rubio-Jara, S. (Eds.), Bifaces y elefantes. La investigación del Paleolítico Inferior en Madrid. Museo Arqueológico Regional de la Comunidad de Madrid, pp. 302-317. Zona Arqueológica 1.

Pons, A., Reille, M., 1988. The holocene-and Upper Pleistocene pollen record from Padul (Granada, Spain): a new study. Palaeogeogr. Palaeoclimatol. Palaeoecol. 66, 243-249.

Reille, M., de Beaulieu, J.L., 1995. Long Pleistocene récords from the Praclaux Crater, South Central France. Quat. Res. 44, 205-215.

Reille, M., de Beaulieu, J.L., Svobodova, V., Andrieu-Ponel, V. , Goeury, C., 2000. Pollen analytical biostratigraphy of the last five climatic cycles from a long continental sequence from the Velay región (Massif Central, France). J. Quat. Sci. 15, 665-685.

Rodrigo-Gámiz, M., Martínez-Ruiz, F., Rodríguez-Tovar, F.J., Jiménez-Espejo, F.J., Pardo-Igúzquiza, E., 2013. Millennial- to centennial-scale climate periodicities and forcing mechanisms in the westernmost Mediterranean for the past 20,000 yr. Quat. Res. 81 (1), 78-93.

Rodríguez, J., Burjachs, F., Cuenca-Bescós, G., García, N., Van der Made, J., Pérez González, A., Blain, H.A., Expósito, I., López-García, J.M., García Antón, M., Allué, E., Cáceres, I., Huguet, R., Mosquera, M., Ollé, A., Rosell, J., Parés, J.M. Rodríguez, X.P., Díez, C., Rofes, J., Sala, R., Saladié, P., Vallverdú, J., Bennasar, M.L Blasco, R., Bermúdez de Castro, J.M., Carbonell, E., 2011. One million years of cultural evolution in a stable environment at Atapuerca (Burgos, Spain). Quat. Sci. Rev. 30, 1396-1412.

Roucoux, K.H., Tzedakis, P.C., de Abreu, L., Shackleton, N.J., 2006. Climate and vegetation changes 180000 to 345000 years ago recorded in a Deep-sea core off Portugal. Earth Planet Sci. Lett. 249, 307-325.

Rubio-Jara, S., Panera Gallego, J., Rodríguez de Tembleque, J., Santonja, M., PérezGonzález, A., 2016. Large flake Acheulean in the middle of Tagus basin (Spain): Middle stretch of the river Tagus valley and lower stretches of the rivers Jarama and Manzanares valleys. Quat. Int. 411, 349-366.

Ruddiman, W.F., 2006. Orbital changes and climate. Quat. Sci. Rev. 25, 3092-3112.

Ruiz Zapata, M.B., Dorado Valiño, M., Valdeolmillos, A., Gil García, M.J., Martín Arroyo, T., Pérez González, A., 2004. Registro paleoambiental y paleoclimático del Pleistoceno Medio y Superior en depósitos fluviales del valle del Tajo (Toledo). In: Baquedano, E., Rubio-Jara, S. (Eds.), Miscelánea en homenaje a Emiliano Aguirre (Paleontología), Zona Arqueológica 4, pp. 506-517.

Ruiz Zapata, M.B., Gil García, M.J. Dorado Valiño, M., Valdeolmillos, A., 2005, El paisaje vegetal durante el Pleistoceno medio en el interior de peninsular. In: Santonja, M., Pérez-González, A. (Eds.), Los yacimientos paleolíticos de Ambrona y Torralba (Soria), Zona Arqueológica 5, pp. 214-220.

Ruiz Zapata, M.B., Gil García, M.J., Panera, J., Rubio-Jara, S., Pérez-González, A., 2017 Paisaje vegetal y clima durante el Pleistoceno Medio en la cuenca media (Valdocarros) y alta (Redueña) del río Jarama (Madrid) a través del análisis polínico. Geogaceta 61, 35-38.

Sánchez-Goñi, M.F., Eynaud, F., Turon, J.L., Shackleton, N.J., 1999. High resolution palynological record off the Iberian margin: direct land-sea correlation for the Last Interglacial complex. Earth Planet Sci. Lett. 171, 123-137.
Santonja, M., López, N., Pérez- González, A. (Eds.), 1980. Ocupaciones achelenses en el valle del Jarama. Arqueología y Paleontología, I. Diputación Provincial de Madrid.

Sesé, C., Panera, J., Rubio-Jara, S., Pérez-González, A., 2011. Micromamíferos de Pleistoceno Medio y Pleistoceno Superior en el Valle del Jarama: yacimientos de Valdocarros y HAT (Madrid, España). Estud. Geol. 67 (1), 131-151.

Sesé, C., Sevilla, P., 1996. Los micromamíferos del Cuaternario peninsular español: Cronoestratigrafía e implicaciones bioestratigráficas. Revista Española de Paleontología, № Extraordinario 278-287.

Sesé, C., Soto, E., 2000. Vertebrados del Pleistoceno de Madrid. In: Morales, J., Nieto, M., Amezua, L., Fraile, S., Gómez, E., Herráez, E., Peláez-Campomanes, P., Salesa, M.J., Sánchez, I.M., Soria, D. (Eds.), El patrimonio paleontológico de la Comunidad de Madrid. Floras y Faunas (Arqueología, Paleontología y Etnografía), vol. 6, pp. 216-243.

Silva, P.G., 2003. El valle inferior del Manzanares (Cuenca de Madrid, España). Volumen en Homenaje a D. Manuel Hoyos. Estud. Geol. 59, 107-131.

Silva, P.G., López-Recio, M., Tapias, F., Roquero, E., Morín de Pablos, J., Rus, I., Carrasco-García, P., Giner-Robles, J.L., Rodríguez-Pascua, M.A., Pérez-López, R. 2013. Stratigraphy of the Arriaga Palaeolithic sites. Implications for the geomorphologica evolution recorded by thickened fluvial sequences within the Manzanares River valley (Madrid Neogene Basin, central Spain). Geomorphology 196, 138-161.

Solomon, S., Qin, D., Manning, M., Marquis, M., Averyt, K., Tignor, M.M.B., 2007. Climate change 2007: the Physical science basis: summary for policymakers. In: Contribution of Working Group I to the Fourth Assessment Report of the Intergovernmental Panel on Climate Change IPCC. Cambridge University Press, Cambridge.

Tzedakis, P.C., 2010. The MIS 11-MIS 1 analogy, southern European vegetation,atmospheric methane and the "early anthropogenic hypothesis". Clim. Past 6, 131-144.

Tzedakis, P.C., Emerson, B.C., Hewitt, G.M., 2013. Cryptic or mystic? Glacial tree refugia in northern Europe. Trends Ecol. Evol. 28 (2), 696-704, 1.

Tzedakis, P.C., Frogley, M.R., Heaton, T.H.E., 2003. Last Interglacial conditions in southern Europe: evidence from Ioannina, northwest Greece. Global Planet. Change 36, 157-170.

Tzedakis, P.C., Hooghiemstra, H., Pälike, H., 2006. The last 1.35 million years at Tenaghi Philippon: revised chronostratigraphy and long-term vegetation trends. Quat. Sci. Rev. 25 (23), 3416-3430.

Tzedakis, P.C., McManus, J.F., Hooghiemstra, H., Oppo, D.W., Wijmstra, T.A., 2003b. Comparison of changes in vegetation in northeast Greece with records of climate variability on orbital and suborbital frequencies over the last 450000 years. Earth Planet Sci. Lett. 212, 197-212.

Uribelarrea, D., 2008. Dinámica y evolución de las llanuras aluviales de los ríos Manzanares, Jarama y Tajo, entre las ciudades de Madrid y Toledo. Doctoral dissertation. Universidad Complutense de Madrid. http://eprints.ucm.es/8746/ 1/T30848bis.pdf.

Van Kolfschoten, T.H., Gibbard, P.L., Knudsenc, K.L., 2003. The eemian interglacial: a global perspective. Introduction. Global Planet. Change 36, 147-149.

Volgel, H., Wagner, B., Zanchetta, G., Sulpizio, R., Rosen, P., 2010. A paleoclimate record with tephrochronological age control for the last glacial-interglacia cycle from Lake Othrid, Albania and Macedonia. J. Paleolimnol. 44, 295-310.

Wijmstra, T.A., Smit, A., 1976. Palynology of the middle part (30-78 meters) of the $120 \mathrm{~m}$ deep section in Northern Greece (Macedonia). Acta Bot. Neerl. 25, 297-312.

Yravedra, J., Domínguez-Rodrigo, M., Santonja, M., Pérez- González, A., Panera, J. Rubio-Jara, S., Baquedano, E., 2010. Cut marks on the Middle Pleistocene elephant carcass of Áridos 2 (Madrid, Spain). J. Archaeol. Sci. 37, 2469-2476.

Yravedra, J., Rubio-Jara, S., Panera, J., Uribelarrea, D., Pérez-González, A., 2012. Elephants and subsistence. Evidence of the human exploitation of extremely large mammal bones from the Middle Palaeolithic site of PRERESA (Madrid, Spain). J. Archaeol. Sci. 39, 1063-1071. 